Research Paper

\title{
GSTM1 and GSTT1 polymorphisms are associated with increased bladder cancer risk: Evidence from updated meta-analysis
}

\author{
Cui $\mathrm{Yu}^{1}$, Chen Hequn ${ }^{1}$, Liu Longfei ${ }^{1}$, Wang Long ${ }^{1}$, Chen $\mathrm{Zhi}^{1}$, Zeng Feng ${ }^{1}$, Chen \\ Jinbo' ${ }^{1}$, Li Chao ${ }^{1}$, Zu Xiongbing ${ }^{1}$ \\ ${ }^{1}$ Department of Urology, Xiangya Hospital, Central South University, Changsha, Hunan 410000, China \\ Correspondence to: Zu Xiongbing, email: zuxbxy@126.com
}

Keywords: GSTM1, GSTI, polymorphism, bladder cancer

Received: September 06, $2016 \quad$ Accepted: November 16, $2016 \quad$ Published: November 29, 2016

\section{ABSTRACT}

Background: Previous studies have indicated association between GSTM1 and GSTT1 gene polymorphisms and bladder cancer susceptibility, but the results have been inconclusive. Here, we performed a meta-analysis to investigate the association between GSTM1/GSTT1 deletion polymorphisms and bladder cancer susceptibility.

Methods: We searched for all studies investigating the association between GSTM1 or GSTT1 polymorphism and bladder cancer susceptibility in Pubmed, Web of Knowledge, and the Cochrane Central Search Library. A systematic review and metaanalysis were performed. Subgroup analyses were performed on different ethnicity, population-based and smoking status.

Results: Our search identified 63 studies. GSTM1 null, GSTT1 null and GSTM1/GSTT1 double-null genotypes were associated with increased risk of bladder cancer (OR: 1.36 95\% CI: 1.25-1.47, P<0.01; OR: 1.13 95\% CI: 1.02-1.25, P<0.01; OR: 1.84 95\% CI: 1.50-2.26, P<0.01). Subgroup analyses indicated that the GSTM1null genotype was associated with increased risk of bladder cancer in Caucasians and Asians, while the GSTT1-null genotype was associated with increased risk of bladder cancer in Caucasians. The GSTM1/GSTT1 double-null genotype was associated with increased risk of bladder cancer in Caucasians, Asians, and Africans. Stratified analyses of population-based associations indicated increased bladder cancer risk associated with GSTM1-null and GSTM1/GSTT1 double-null genotypes in hospital-based and population-based studies. GSTM1 deletion was associated with increased bladder cancer risk in both smokers and nonsmokers. Non-smokers with the GSTM1/GSTT1 double-null genotype had an increased bladder cancer risk.

Conclusion: This meta-analysis demonstrates that the GSTM1-null, GSTT1-null, and GSTM1/GSTT1 double-null genotypes are associated with increased bladder cancer risk.

\section{INTRODUCTION}

Bladder cancer is the ninth most common malignancy worldwide, and the fourth most common malignancy in the United States $[1,2]$. $70 \%$ of bladder cancers are nonmuscle invasive, whereas the remaining $30 \%$ are muscle invasive bladder cancers [3]. Life style and occupational exposure are the main etiological factors in bladder cancer [4]. However, only a small percentage of people develop bladder cancer after exposure to these environmental factors, indicating that genetic susceptibility plays an important role in bladder cancer development.
Glutathione S-transferases (GSTs) are members of a multigene family of phase II enzymes, which are involved in the detoxification of various carcinogens, and have been recognized as an important factor in bladder cancer development [5]. GSTM1 and GSTT1 genes are members of the GST family. GSTM1 and GSTT1 homozygous deletions are associated with reduced detoxification function, increased susceptibility to cytogenetic damage, and increased risk of cancer [6-8]. Previous meta-analyses have indicated an association of GSTM1 and GSTT1 deletion polymorphisms with increased bladder cancer risk [9-11]; however, the results have been inconsistent. Some overlapping studies were not excluded and several 
published studies were missing in their analysis [12, 13]. Here, we performed an updated meta-analysis to investigate the association between GSTM1/GSTT1 deletion polymorphisms and bladder cancer susceptibility.

\section{RESULTS}

256 studies were identified from the database or manual search. According to the selection criteria, 193 studies were excluded, resulting in 63 studies for analysis [5, 12, 14-75]. (Figure 1) From these studies, data were available from 46 studies on GSTM1 null genotype (12751 cases and 15519 controls), 54 studies on GSTT1 null genotype (11817 cases and 14805 controls) and 11 studies on GSTM1/GSTT1 double-null genotype (1485 cases and 2230 controls). The essential information of the included studies is listed in Table 1.

\section{GSTM1}

46 studies described the relationship between GSTM1 polymorphism and bladder cancer susceptibility, involving 28270 individuals. Statistical heterogeneity between trials was observed in the analysis $\left(\mathrm{I}^{2}=52.4 \%\right.$, $\mathrm{P}<0.01)$; thus, a random-effects model was used. The pooled meta-analysis showed that the GSTM1 null genotype was associated with increased risk of bladder cancer. The pooled summary of the OR was $1.36(95 \%$ CI: 1.25-1.47, $\mathrm{P}<0.01$ ) (Figure 2). Subgroup analyses were performed on the different ethnicity, populationbased and smoking (Table 2). The GSTM1 null genotype was associated with the elevated risk of bladder cancer in Caucasians $(\mathrm{OR}=1.34,95 \% \mathrm{CI}=1.21-1.48)$ and Asians $(\mathrm{OR}=1.50,95 \% \mathrm{CI}=1.31-1.71)$. Stratified analyses of population-based association showed a significant association of elevated bladder cancer risk with GSTM1 deletion in hospital-based (HB) studies ( $\mathrm{OR}=1.42$, $95 \% \mathrm{CI}=1.30-1.56)$ and population-based (PB) studies $(\mathrm{OR}=1.22,95 \% \mathrm{CI}=1.07-1.40)$. The GSTM1 null genotype was also associated with elevated risk of bladder cancer stratified by smoking status (OR 1.37, 95\%CI: 1.19-1.59 for smokers and OR 1.26, 95\%CI: 1.08-1.48 for nonsmokers, respectively).

\section{GSTT1}

54 studies described the relationship between GSTT1 polymorphism and bladder cancer susceptibility, involving 26622 individuals. Statistical heterogeneity between trials was observed in the analysis $\left(\mathrm{I}^{2}=56.3 \%\right.$,

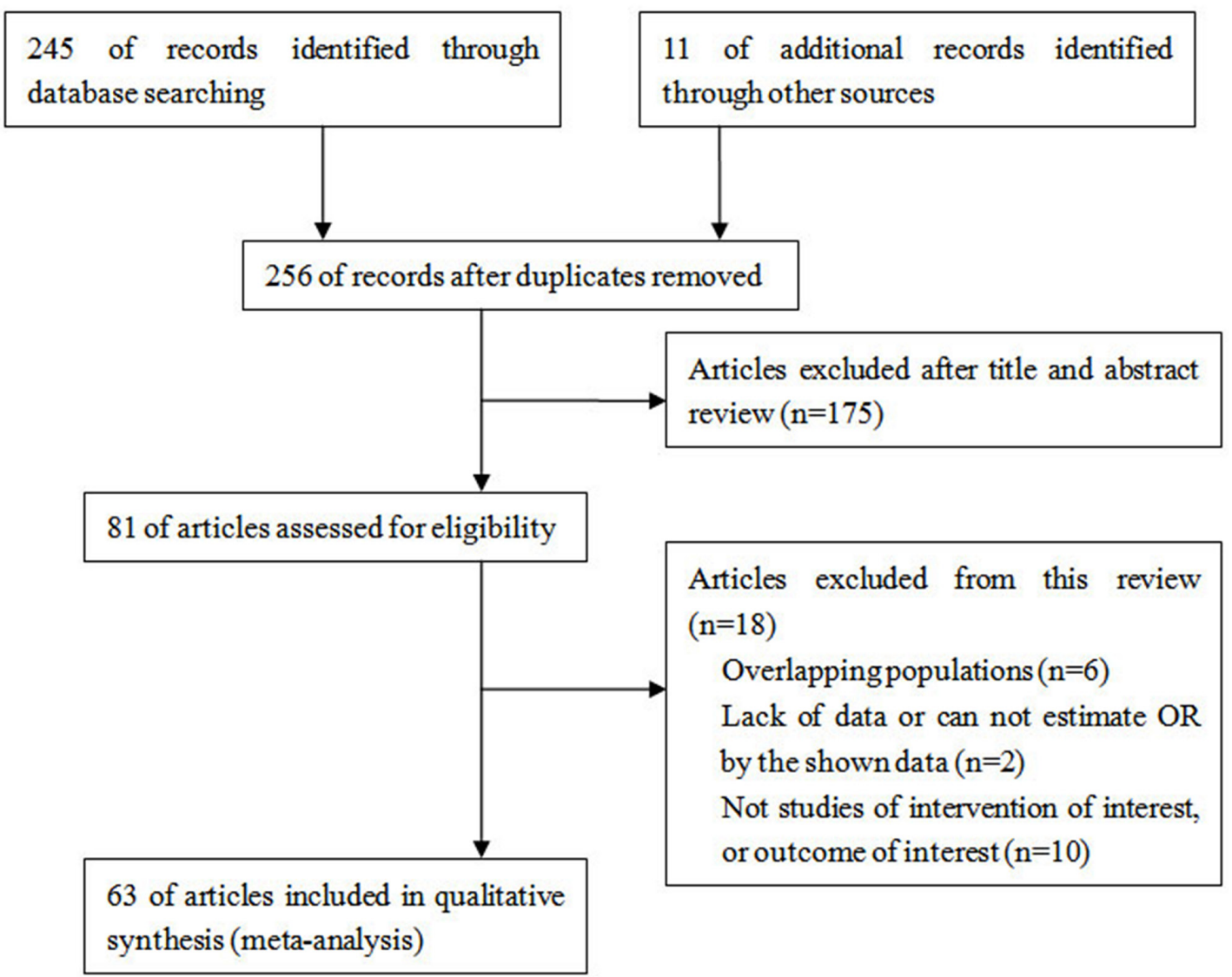

Figure 1: Flow chart of article selection. 
Table 1: Characteristics of patients in the studies included

\begin{tabular}{|c|c|c|c|c|c|c|c|c|c|c|}
\hline \multirow[t]{2}{*}{ Study } & \multirow[t]{2}{*}{ Year } & \multirow[t]{2}{*}{ Ethnicity } & \multirow[t]{2}{*}{$\begin{array}{l}\text { Source of } \\
\text { controls }\end{array}$} & \multirow[t]{2}{*}{$\begin{array}{l}\text { Study } \\
\text { quality }\end{array}$} & \multicolumn{2}{|c|}{ GSMT1 null } & \multicolumn{2}{|c|}{ GSTT1 null } & \multicolumn{2}{|c|}{$\begin{array}{c}\text { GSTM1/ GSTT1 } \\
\text { null }\end{array}$} \\
\hline & & & & & case $^{a}$ & contro $^{a}$ & $\operatorname{case}^{a}$ & contro $^{a}$ & case $^{a}$ & contro $^{a}$ \\
\hline Ceylan & 2015 & Caucasian & HB & 9 & $22 / 43$ & $31 / 39$ & $19 / 46$ & $9 / 61$ & $8 / 57$ & $8 / 62$ \\
\hline Matic & 2014 & Caucasian & HB & 8 & $80 / 63$ & $56 / 58$ & $36 / 101$ & $32 / 82$ & & \\
\hline Reszka & 2014 & Caucasian & PB & 9 & $149 / 95$ & $165 / 200$ & $30 / 212$ & $77 / 288$ & & \\
\hline Berber & 2013 & Caucasian & PB & 8 & $54 / 60$ & $51 / 63$ & $31 / 83$ & $16 / 98$ & $11 / 103$ & $7 / 107$ \\
\hline Kang & 2013 & Asian & PB & 8 & $65 / 45$ & $103 / 117$ & $64 / 46$ & $128 / 92$ & & \\
\hline $\begin{array}{l}\text { Henríquez- } \\
\text { Hernández }\end{array}$ & 2012 & Caucasian & $\mathrm{HB}$ & 8 & $23 / 67$ & $17 / 64$ & $60 / 30$ & $40 / 41$ & $17 / 73$ & $8 / 73$ \\
\hline Schwender & 2012 & Caucasian & HB & 9 & $909 / 663$ & $863 / 876$ & & & & \\
\hline Lesseur & 2012 & Caucasian & HB & 7 & $378 / 275$ & $508 / 420$ & $106 / 556$ & $143 / 780$ & & \\
\hline Zhang & 2012 & Caucasian & HB & 9 & $381 / 329$ & $402 / 380$ & & & & \\
\hline Ovsiannikov & 2012 & Caucasian & HB & 6 & $102 / 94$ & $122 / 113$ & $33 / 163$ & $47 / 188$ & & \\
\hline Marenne & 2012 & Caucasian & HB & 7 & $488 / 285$ & $402 / 357$ & & & & \\
\hline Öztürk & 2011 & Caucasian & PB & 9 & $98 / 78$ & $51 / 46$ & & & & \\
\hline Rouissi & 2011 & African & HB & 8 & $63 / 62$ & $56 / 69$ & $30 / 95$ & $38 / 87$ & & \\
\hline $\begin{array}{l}\text { Salinas- } \\
\text { Sánchez }\end{array}$ & 2011 & Caucasian & HB & 8 & & & $42 / 148$ & $25 / 138$ & & \\
\hline Moore & 2011 & Caucasian & PB & 9 & & & $210 / 794$ & $237 / 942$ & & \\
\hline Goerlitz & 2011 & Caucasian & PB & 7 & & & $147 / 470$ & $156 / 464$ & & \\
\hline Cantor & 2010 & Caucasian & HB & 6 & & & $136 / 542$ & $160 / 550$ & & \\
\hline Lin & 2009 & Caucasian & PB & 8 & $312 / 292$ & $286 / 324$ & & & & \\
\hline Altayli & 2009 & Caucasian & HB & 7 & $58 / 77$ & $65 / 63$ & $31 / 104$ & 9/119 & & \\
\hline Grando & 2009 & Multiracial & PB & 8 & $40 / 60$ & $33 / 67$ & & & & \\
\hline Song & 2009 & Asian & HB & 9 & $131 / 77$ & $108 / 104$ & $110 / 98$ & $105 / 107$ & $77 / 131$ & $50 / 162$ \\
\hline Zupa & 2009 & Caucasian & PB & 7 & $13 / 10$ & $68 / 53$ & & & & \\
\hline Covolo & 2008 & Caucasian & HB & 8 & $17 / 9$ & $14 / 16$ & $42 / 155$ & $33 / 178$ & & \\
\hline Golka & 2008 & Caucasian & HB & 7 & $184 / 109$ & $88 / 88$ & & & & \\
\hline Shao & 2008 & Asian & HB & 8 & $85 / 117$ & $81 / 191$ & & & & \\
\hline Cengiz & 2007 & Caucasian & HB & 9 & $18 / 33$ & $11 / 42$ & $18 / 99$ & $11 / 42$ & & \\
\hline $\begin{array}{l}\text { Murta- } \\
\text { Nascimento }\end{array}$ & 2007 & Caucasian & HB & 8 & $428 / 251$ & $367 / 368$ & & & & \\
\hline Zhao & 2007 & Caucasian & HB & 9 & $324 / 298$ & $317 / 316$ & $103 / 520$ & $519 / 115$ & & \\
\hline Kellen & 2007 & Caucasian & PB & 7 & & & $30 / 164$ & $61 / 319$ & & \\
\hline McGrath & 2006 & Multiracial & HB & 8 & $109 / 161$ & $483 / 439$ & $35 / 156$ & $148 / 776$ & $18 / 173$ & $78 / 844$ \\
\hline Kogevinas & 2006 & Caucasian & HB & 7 & & & $24 / 75$ & $17 / 74$ & & \\
\hline García-Closas & 2005 & Caucasian & HB & 7 & $716 / 422$ & $571 / 561$ & $230 / 916$ & $248 / 889$ & & \\
\hline Karagas & 2005 & Multiracial & PB & 9 & $163 / 115$ & $211 / 140$ & $53 / 301$ & $83 / 458$ & & \\
\hline Kellen & 2005 & Caucasian & PB & 7 & $312 / 267$ & $597 / 466$ & & & & 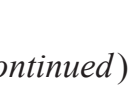 \\
\hline
\end{tabular}




\begin{tabular}{|c|c|c|c|c|c|c|c|c|c|c|}
\hline \multirow[t]{2}{*}{ Study } & \multirow[t]{2}{*}{ Year } & \multirow[t]{2}{*}{ Ethnicity } & \multirow[t]{2}{*}{$\begin{array}{c}\text { Source of } \\
\text { controls }\end{array}$} & \multirow[t]{2}{*}{$\begin{array}{l}\text { Study } \\
\text { quality }\end{array}$} & \multicolumn{2}{|c|}{ GSMT1 null } & \multicolumn{2}{|c|}{ GSTT1 null } & \multicolumn{2}{|c|}{$\begin{array}{c}\text { GSTM1/ GSTT1 } \\
\text { null }\end{array}$} \\
\hline & & & & & case $^{a}$ & contro $^{a}$ & case $^{a}$ & contro $^{a}$ & case $^{a}$ & contro $^{a}$ \\
\hline Kim & 2005 & Asian & HB & 8 & $92 / 61$ & $73 / 80$ & $71 / 82$ & $89 / 64$ & & \\
\hline Sobti & 2005 & Asian & PB & 7 & $37 / 63$ & $24 / 52$ & $30 / 70$ & $11 / 65$ & & \\
\hline Srivastava & 2005 & Asian & $\mathrm{PB}$ & 9 & $43 / 63$ & $140 / 230$ & & & & \\
\hline Broberg & 2005 & Caucasian & $\mathrm{PB}$ & 8 & & & $7 / 54$ & $22 / 132$ & & \\
\hline Saad & 2005 & Caucasian & PB & 9 & & & $26 / 46$ & $14 / 67$ & & \\
\hline Hung & 2004 & Caucasian & HB & 8 & $132 / 69$ & $112 / 102$ & $43 / 158$ & $33 / 181$ & $28 / 173$ & $19 / 195$ \\
\hline Moore & 2004 & Multiracial & $\mathrm{PB}$ & 7 & $54 / 52$ & $49 / 60$ & $17 / 89$ & $12 / 97$ & 9/97 & $6 / 103$ \\
\hline Srivastava & 2004 & Asian & HB & 7 & $42 / 64$ & $54 / 128$ & $28 / 78$ & $29 / 153$ & $16 / 90$ & $9 / 173$ \\
\hline Sanyal & 2004 & Caucasian & PB & 7 & & & $66 / 204$ & $12 / 110$ & & \\
\hline Chen & 2004 & Asian & PB & 8 & & & $32 / 30$ & $51 / 30$ & & \\
\hline Jeong & 2003 & Asian & HB & 6 & $75 / 51$ & $99 / 105$ & $68 / 58$ & $113 / 91$ & & \\
\hline $\begin{array}{l}\text { Gago- } \\
\text { Dominguez }\end{array}$ & 2003 & Multiracial & PB & 7 & & & $50 / 146$ & $34 / 142$ & & \\
\hline Giannakopoulos & 2002 & Caucasian & HB & 9 & $56 / 33$ & $56 / 91$ & $5 / 84$ & $16 / 131$ & & \\
\hline Lee & 2002 & Asian & HB & 8 & $149 / 83$ & $86 / 79$ & $135 / 97$ & $85 / 80$ & $83 / 149$ & $37 / 128$ \\
\hline $\mathrm{Ma}$ & 2002 & Asian & $\mathrm{PB}$ & 9 & $180 / 137$ & $99 / 83$ & $29 / 32$ & $88 / 94$ & & \\
\hline Kim & 2002 & Asian & PB & 8 & & & $91 / 125$ & $228 / 221$ & & \\
\hline Aktas & 2001 & Caucasian & HB & 6 & $56 / 47$ & $70 / 132$ & & & & \\
\hline Törüner & 2001 & Caucasian & PB & 7 & $75 / 46$ & $55 / 66$ & $24 / 97$ & $21 / 100$ & & \\
\hline Kim & 2000 & Asian & HB & 7 & $78 / 34$ & $123 / 97$ & $47 / 65$ & $101 / 119$ & & \\
\hline Schnakenberg & 2000 & Caucasian & PB & 8 & $93 / 64$ & $129 / 94$ & $28 / 129$ & $48 / 175$ & & \\
\hline Steinhoff & 2000 & Caucasian & HB & 7 & $80 / 55$ & $57 / 70$ & $20 / 115$ & $17 / 110$ & $12 / 123$ & $4 / 123$ \\
\hline Peluso & 2000 & Caucasian & $\mathrm{HB}$ & 7 & & & $14 / 108$ & $6 / 48$ & & \\
\hline Salagovic & 1999 & Caucasian & $\mathrm{PB}$ & 9 & $40 / 36$ & $123 / 125$ & $21 / 55$ & $42 / 206$ & & \\
\hline Lee & 1999 & Asian & HB & 6 & & & $93 / 65$ & $66 / 65$ & & \\
\hline Abdel-Rahman & 1998 & African & $\mathrm{PB}$ & 7 & $26 / 11$ & $15 / 19$ & $17 / 20$ & $5 / 29$ & $14 / 23$ & $3 / 31$ \\
\hline Katoh & 1998 & Asian & PB & 7 & & & $46 / 66$ & $53 / 59$ & & \\
\hline Salagovic & 1998 & Caucasian & PB & 8 & & & $20 / 47$ & $42 / 206$ & & \\
\hline Brockmoller & 1996 & Caucasian & HB & 6 & $218 / 156$ & $202 / 171$ & & & & \\
\hline Kempkes & 1996 & Caucasian & $\mathrm{PB}$ & 7 & & & $20 / 93$ & $31 / 139$ & & \\
\hline
\end{tabular}

${ }^{\text {a }}$ Null/present.

Abbreviations: HB, hospital-based controls; PB, population-based controls.

$\mathrm{P}<0.01$ ); thus, a random-effects model was used. The pooled meta-analysis showed that the GSTT1 null genotype was associated with elevated risk of bladder cancer. The pooled summary of the OR was $1.13(95 \%$ CI: 1.02-1.25, $\mathrm{P}<0.01$ ) (Figure 3). Subgroup analyses were performed on the different ethnicity, populationbased and smoking (Table 2). The results suggested that the GSTT1 null genotype was associated with the elevated risk of bladder cancer in Caucasians $(\mathrm{OR}=1.23$, $95 \% \mathrm{CI}=1.08-1.40)$. However, no significant association was found in Asians, Africans, and multiracial subjects. Stratified analyses of population-based association showed a weak association of elevated bladder cancer risk with GSTT1 deletion in HB studies (OR=1.11, 95\% $\mathrm{CI}=0.98$ - 
1.27) and $\mathrm{PB}$ studies $(\mathrm{OR}=1.15,95 \% \mathrm{CI}=1.00-1.33)$, but without statistical significance. There was no significant association between GSTM1 null genotype and bladder cancer risk stratified by smoking status (OR 1.05, 95\%CI: 0.93-1.19 for smokers and OR 1.07, 95\%CI: 0.88-1.29 for nonsmokers).

\section{GSTM1/ GSTT1}

11 studies reported the relationship between GSTM1/ GSTT1 double-null and bladder cancer susceptibility, involving 3715 individuals. Statistical heterogeneity between trials was not observed in the analysis $\left(\mathrm{I}^{2}=4 \%\right.$, $\mathrm{P}=0.41$ ), so a fixed-effects model was used. The pooled meta-analysis showed that individuals with GSTM1/ GSTT1 double-null genotype were at a higher risk to develop bladder cancer than individuals with GSTM1 or GSTT1 present. The pooled summary of the OR was 1.84 (95\% CI: 1.50-2.26, P<0.01) (Figure 4). Subgroup analyses were performed on the different ethnicity, population-based and smoking (Table 2). The GSTM1/ GSTT1 double-null genotype was associated with the elevated risk of bladder cancer in Caucasians $(\mathrm{OR}=1.23,95 \% \mathrm{CI}=1.08-1.40)$, Asians $(\mathrm{OR}=2.05,95 \% \mathrm{CI}=1.53-2.74)$ and Africans $(\mathrm{OR}=6.29$, $95 \% \mathrm{CI}=1.62-24.47)$. Stratified analyses of populationbased association showed association of elevated bladder cancer risk with GSTM1/ GSTT1 double-null in HB studies $(\mathrm{OR}=1.73,95 \% \mathrm{CI}=1.45-2.23)$ and $\mathrm{PB}$ studies $(\mathrm{OR}=2.28$,

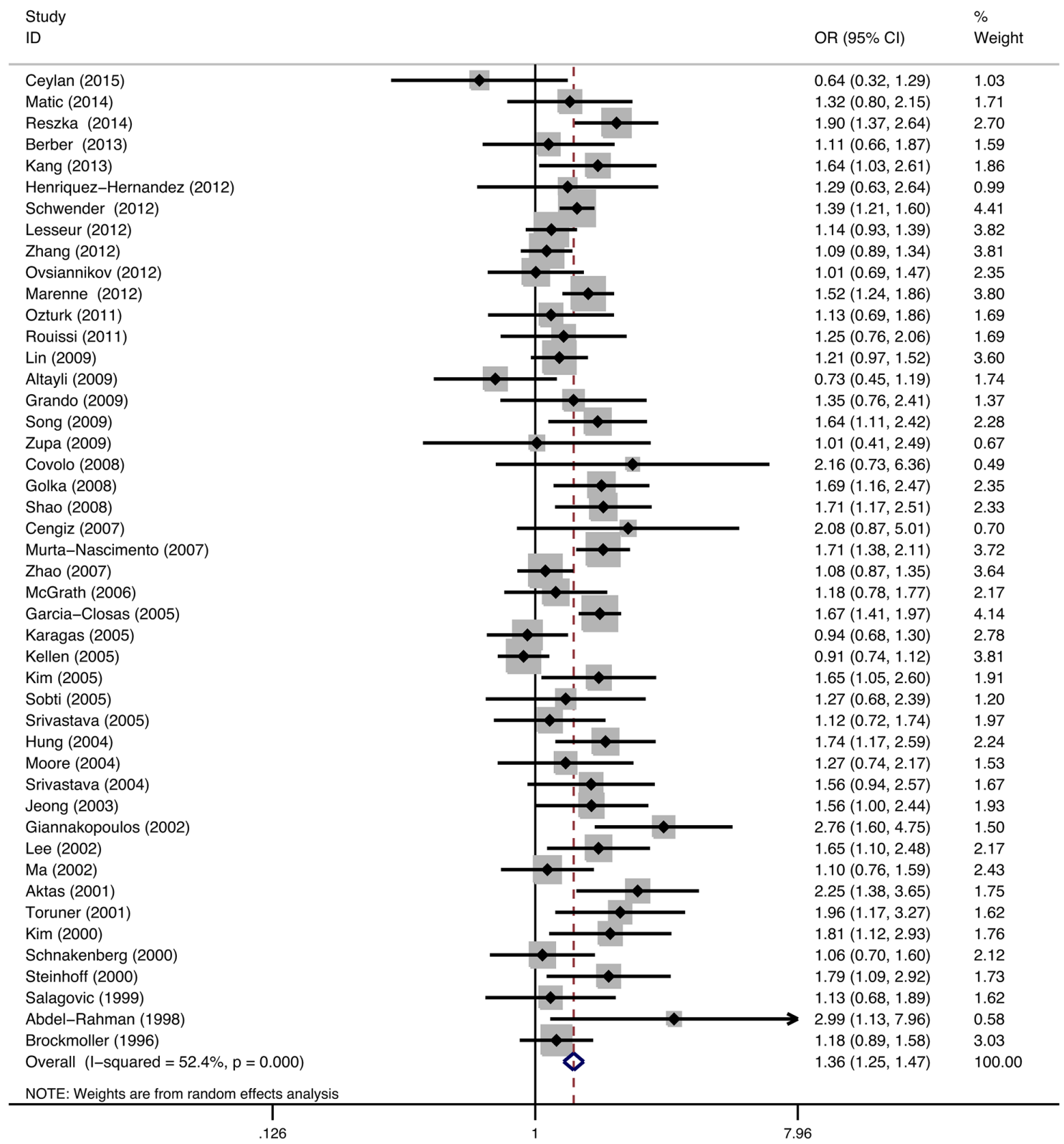

Figure 2: Meta-analysis of GSTM1 gene polymorphism and bladder cancer risk. 
Table 2: Subgroup analysis of GSTM1/GSTT1 polymorphism and bladder cancer risk

\begin{tabular}{|c|c|c|c|c|c|c|c|c|c|c|c|c|}
\hline Subgroup & Number & & GSTM1 & & Number & & GSTT1 & & Number & & GSTM1/GSTT & \\
\hline Ethnicity & & $\begin{array}{c}\text { Null } \\
\text { percentage } \\
(\%)^{\#}\end{array}$ & OR( $(95 \% \mathrm{CI})$ & Heterogeneity & & $\begin{array}{c}\text { Null } \\
\text { percentage } \\
(\%)^{\#}\end{array}$ & OR( $(95 \% \mathrm{CI})$ & Heterogeneity & & $\begin{array}{c}\text { Null } \\
\text { percentage } \\
(\%)^{\#}\end{array}$ & OR( $(95 \% \mathrm{CI})$ & Heterogeneity \\
\hline Caucasian & 29 & $57 / 50$ & $\begin{array}{c}1.34(1.21-1.48) \\
\mathrm{P}<0.01\end{array}$ & $\mathrm{p}<0.01 ; \mathrm{I}^{2}=63.9 \%$ & 38 & $22 / 19$ & $\begin{array}{c}1.23(1.08-1.40) \\
\mathrm{P}<0.01\end{array}$ & $\mathrm{P}<0.01 ; \mathrm{I}^{2}=61.0 \%$ & 5 & $13 / 7$ & $\begin{array}{c}1.77(1.20-2.60) \\
\mathrm{P}<0.01\end{array}$ & $\mathrm{p}=0.76 ; \mathrm{I}^{2}=0 \%$ \\
\hline Asians & 11 & $55 / 43$ & $\begin{array}{c}1.50(1.31-1.71) \\
\mathrm{P}<0.01\end{array}$ & $\mathrm{p}=0.77 ; \mathrm{I}^{2}=0 \%$ & 10 & $19 / 52$ & $\begin{array}{c}0.88(0.75-1.04) \\
P=0.14\end{array}$ & $\mathrm{p}=0.25 ; \mathrm{I}^{2}=21.1 \%$ & 3 & $32 / 17$ & $\begin{array}{c}2.05(1.53-2.74) \\
\mathrm{P}<0.01\end{array}$ & $\mathrm{p}=0.46 ; \mathrm{I}^{2}=0 \%$ \\
\hline Africans & 2 & $55 / 45$ & $\begin{array}{c}1.74(0.76-3.99) \\
\mathrm{p}=0.19\end{array}$ & $\mathrm{p}=0.12 ; \mathrm{I}^{2}=59 \%$ & 2 & $30 / 36$ & $\begin{array}{c}0.79(0.52-1.22) \\
P=0.29\end{array}$ & $\mathrm{p}=0.61 ; \mathrm{I}^{2}=0 \%$ & 1 & $38 / 9$ & $\begin{array}{c}6.29(1.62-24.47) \\
\mathrm{P}<0.01\end{array}$ & - \\
\hline multiracial & 4 & $43 / 30$ & $\begin{array}{c}0.10(0.89-1.36) \\
\mathrm{p}=0.38\end{array}$ & $\mathrm{p}=0.62 ; \mathrm{I}^{2}=0 \%$ & 4 & $22 / 17$ & $\begin{array}{c}0.13(0.90-1.42) \\
P=0.09\end{array}$ & $\mathrm{p}=0.18 ; \mathrm{I}^{2}=36.3 \%$ & 2 & $9 / 8$ & $\begin{array}{c}1.21(0.75-1.95) \\
\mathrm{P}=0.43\end{array}$ & $\mathrm{p}=0.57 ; \mathrm{I}^{2}=0 \%$ \\
\hline \multicolumn{13}{|l|}{ Study design } \\
\hline HB & 29 & $57 / 46$ & $\begin{array}{c}1.42(1.30-1.56) \\
\mathrm{P}<0.01\end{array}$ & $\mathrm{p}<0.01 ; \mathrm{I}^{2}=52 \%$ & 25 & $26 / 26$ & $\begin{array}{c}1.11(0.97-1.27) \\
P=0.14\end{array}$ & $\mathrm{P}<0.01 ; \mathrm{I}^{2}=48.8 \%$ & 8 & $21 / 11$ & $\begin{array}{c}1.73(1.45-2.23) \\
\mathrm{P}<0.01\end{array}$ & $\mathrm{p}=0.42 ; \mathrm{I}^{2}=0.9 \%$ \\
\hline PB & 17 & $54 / 48$ & $\begin{array}{c}1.22(1.07-1.40) \\
\mathrm{P}<0.01\end{array}$ & $\mathrm{p}=0.05 ; \mathrm{I}^{2}=39.3 \%$ & 29 & $24 / 22$ & $\begin{array}{c}1.15(1.00-1.33) \\
\mathrm{P}=0.06\end{array}$ & $\mathrm{P}<0.01 ; \mathrm{I}^{2}=62.2 \%$ & 3 & $13 / 6$ & $\begin{array}{c}2.28(1.22-4.25) \\
P=0.01\end{array}$ & $\mathrm{p}=0.22 ; \mathrm{I}^{2}=33.7 \%$ \\
\hline \multicolumn{13}{|l|}{ Smoking } \\
\hline Smoker & 17 & $59 / 51$ & $\begin{array}{c}1.37(1.19-1.59) \\
\mathrm{P}<0.01\end{array}$ & $\mathrm{p}=0.04 ; \mathrm{I}^{2}=42.5 \%$ & 16 & $25 / 23$ & $\begin{array}{c}1.05(0.93-1.19) \\
\mathrm{P}=0.40\end{array}$ & $\mathrm{p}=0.17 ; \mathrm{I}^{2}=42.5 \%$ & 1 & $38 / 20$ & $\begin{array}{c}1.18(0.54-2.59) \\
P=0.68\end{array}$ & - \\
\hline Non-smoker & 17 & $54 / 49$ & $\begin{array}{c}1.26(1.08-1.48) \\
\mathrm{P}<0.01\end{array}$ & $\mathrm{p}=0.65 ; \mathrm{I}^{2}=0 \%$ & 16 & $24 / 23$ & $\begin{array}{c}1.07(0.88-1.29) \\
P=0.49\end{array}$ & $\mathrm{p}=0.33 ; \mathrm{I}^{2}=10.4 \%$ & 1 & $35 / 26$ & $\begin{array}{c}2.66(1.22-5.81) \\
P=0.01\end{array}$ & - \\
\hline
\end{tabular}

\#: null genotype percentage of bladder cancer patients/ null genotype percentage of control individuals.

$95 \% \mathrm{CI}=1.22-4.25)$. Only one study reported the relationship between GSTM1/ GSTT1 double-null genotype and the risk of bladder cancer stratified by smoking status; this study showed that non-smokers with GSTM1/ GSTT1 double-null genotype had an elevated bladder cancer risk $(\mathrm{OR}=2.66,95 \% \mathrm{CI}: 1.22-5.81)$.

\section{Sensitivity analysis}

Sensitivity analysis was performed to assess the stability of this meta-analysis result. The influence of the individual datasets on the summary ORs was examined by repeating the meta-analysis after sequentially omitting each study. For GSTM1 null, GSTT1 null, and GSTM1/ GSTT1 double-null genotypes, the ORs were not significantly affected by omitting any individual study.

\section{Publication bias}

The funnel plot for the relationship between GSTM1 null genotype and bladder cancer susceptibility is shown in Figure 5A. The P values for Begg's and Egger's tests were 0.44 and 0.42 , respectively. The results did not reveal any evidence of publication bias in this meta-analysis.

The funnel plot for the relationship between GSTT1 null genotype and bladder cancer susceptibility is shown in Figure 5B. The P values for Begg's and Egger's tests were $<0.01$ and 0.02 , respectively. The results revealed that the publication bias was significant. Five studies were required to make the plot symmetrical (trim and fill method) (Figure 5C). Moreover, LogOR and its 95\% CI altered significantly after performed trim and fill method.

The funnel plot for the relationship between GSTM1/GSTT1 double-null genotype and bladder cancer susceptibility is shown in Figure 5D. The $\mathrm{P}$ values for Begg's and Egger's tests were 0.35 and 0.20 , respectively. The results did not reveal any evidence of publication bias in this meta-analysis.

\section{DISCUSSION}

Both environmental and genetic factors are important in bladder carcinogenesis; however, the exact mechanisms remain unknown. Polymorphisms in GSTs may result in deficiency in GST enzyme activity and increased cancer susceptibility. Previous studies have explored the relationship between GSTM1/GSTT1 deletion polymorphisms and cancer susceptibility. However, the results were inconclusive because of different study designs, and ethnicities and lifestyles of the enrolled subjects.

To quantify the strength of the association between GSTM1/GSTT1 polymorphisms and bladder cancer risk, we performed a meta-analysis of 63 studies. GSTM1 functions in the detoxification of benzene oxide to s-phenylmercapturic acid [76], and its deletion is responsible for the deficiency in key enzyme activity. Our results show that the GSTM1 null genotype is associated with increased bladder cancer risk. GSTT1 also functions in the detoxification of various carcinogens [76]. Our study demonstrates that GSTT1 null genotype is associated with increased bladder cancer risk. The null genotype of both 
GSTM1 and GSTT1 is also associated with increased risk of bladder cancer.

Regarding the different ethnicities, our results suggest that the GSTM1 null genotype is associated with the elevated risk of bladder cancer in Caucasians and Asians. A similar relationship was found between the GSTT1 null genotype and bladder cancer risk in Caucasians. In addition, our results indicate that the GSTM1/GSTT1 double-null genotype is associated with elevated risk of bladder cancer in Caucasians, Asians, and Africans. This discrepancy could be explained by different effects of the GSTM1 and GSTT1 polymorphisms on bladder cancer susceptibility in different ethnic groups. Alternatively, the sample size of Asians and Africans studies might have been small, which would result in an inadequate statistical power to identify a statistically significant effect or generate a fluctuated risk estimate [77]. Stratified analyses of population-based association study showed a significant association of increased bladder cancer risk with GSTM1 null and GSTM1/GSTT1 double-null in HB studies and PB studies. However, this statistical significance was not found between GSTT1 null

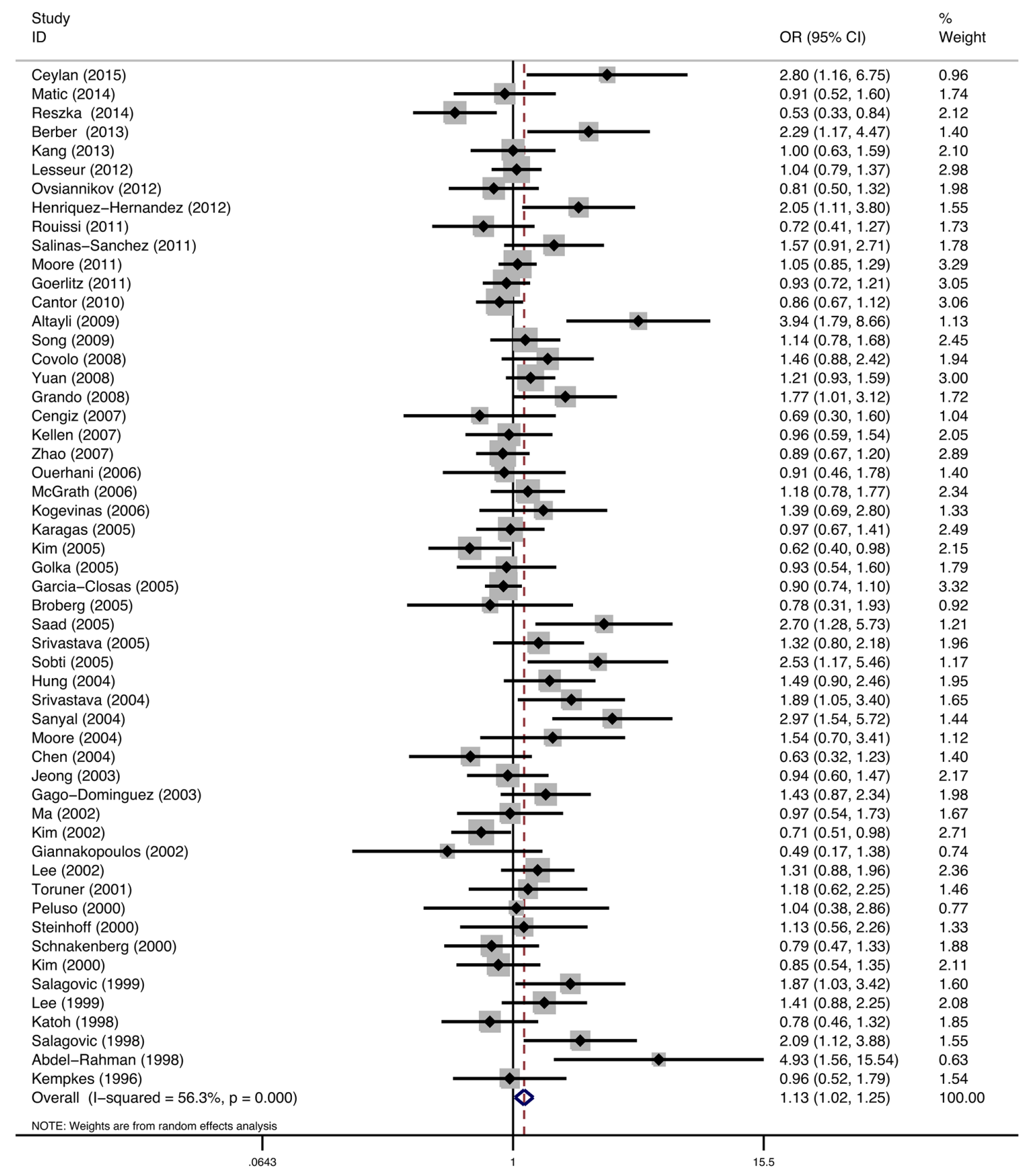

Figure 3: Meta-analysis of GSTT1 gene polymorphism and bladder cancer risk. 


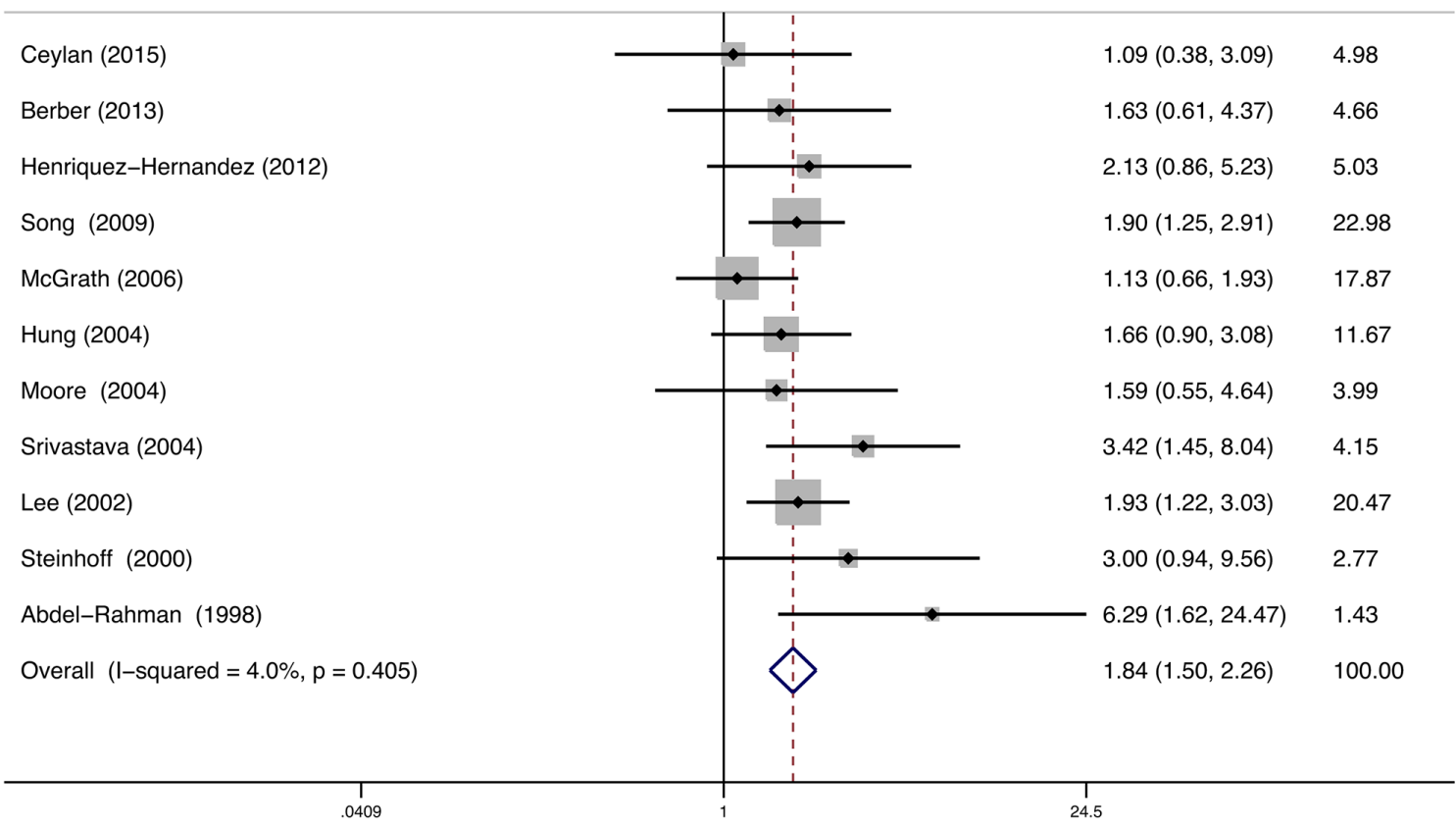

Figure 4: Meta-analysis of GSTM1/GSTT1 double-null gene polymorphism and bladder cancer risk.
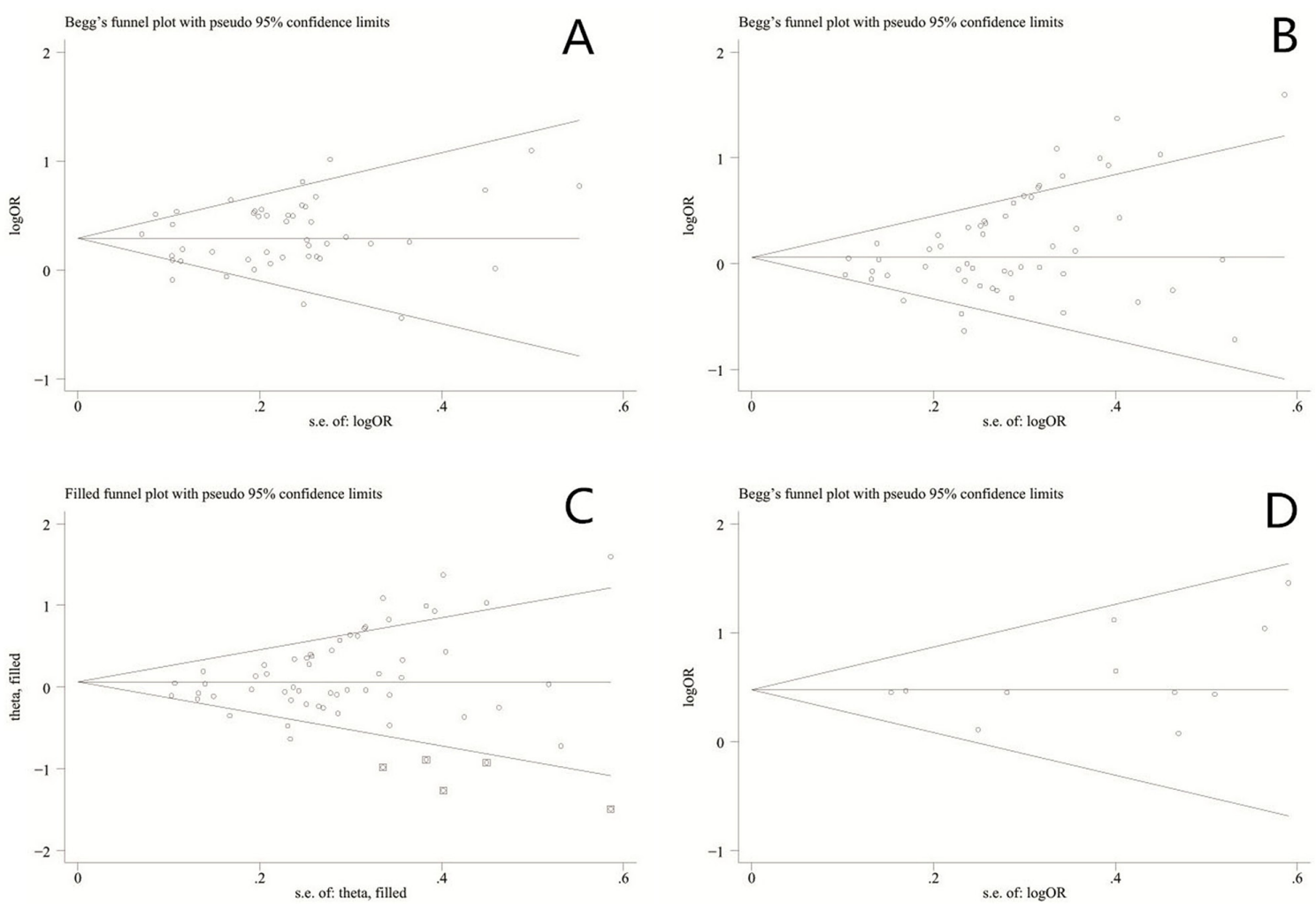

Figure 5: A. Funnel plot of GSTM1 gene polymorphism and bladder cancer risk. B. Funnel plot of GSTT1 gene polymorphism and bladder cancer risk. C. Funnel plot of GSTT1 gene polymorphism and bladder cancer risk (Trim and fill test). D. Funnel plot of GSTM1/ GSTT1 double-null gene polymorphism and bladder cancer risk. 
genotype and bladder cancer risk in HB studies and PB studies. This suggests that the role of GSTT1 deletion on bladder cancer susceptibility is mainly influenced by the different control individuals. It is well known that smoking is one of the main independent risk factors for bladder cancer [78]. After stratification by smoking status, the GSTM1 deletion was associated with an increased bladder cancer risk in both smokers and nonsmokers. However, no statistical significance was found between GSTT1 deletion and smoking status. Non-smokers with GSTM1/GSTT1 double-null genotype had an elevated bladder cancer risk. These inconsistent data may indicate the different GSTs interactions resulting in joint action. The different study weight dictated by study size may also influence the result.

Several limitations should be noted in this metaanalysis. First, several small sample size studies were included in our analysis. However, we also included some large sample size studies. Second, significant heterogeneity between trials was observed in the analysis. This heterogeneity may derive from the differences in ethnicity, population-based or individual lifestyles. Third, we detected a publication bias when we analyzed the association between GSTT1 polymorphism and bladder cancer risk. It is probably because only published and English language papers were enrolled in this study.

In summary, our meta-analysis study indicates that GSTM1 null, GSTT1 null, and GSTM1/GSTT1 double-null genotypes are associated with increased bladder cancer risk. Further high-quality large scale epidemiological studies should be performed to verify the current conclusions.

\section{MATERIALS AND METHODS}

\section{Publication search}

According to the PRISMA guidelines [79], we performed a systematic literature search of Pubmed, Web of Knowledge, and the Cochrane Central Search Library (on May 15, 2016). Key words used included glutathione S-transferase M1, GSTM1, glutathione S-transferase T 1, GSTT1, bladder, cancer, carcinoma, and tumor. All abstracts and review studies on this topic were reviewed. Reference lists of review studies were searched by hand.

\section{Inclusion and exclusion criteria}

The eligible studies had to meet the following inclusion criteria: (1) The studies had to evaluate the association between GSTM1 or GSTT1 polymorphism and bladder cancer risk; (2) The report contained key information that could yield odds ratio (OR) by the data provided; (3) Studies were published in English; and (4) Conference abstracts, reviews and unpublished reports were not included. Duplicate or insufficient reports were excluded. Figure 1 shows the procedure of identifying and selecting studies.

\section{Data extraction}

Two authors extracted the data from the eligible articles according to the inclusion criteria. Any disagreement was resolved during a discussion with a third author. The literature data were extracted individually. OR and its 95\% confidence intervals (CI) were used to estimated the association between the GSTM1 or GSTT1 null polymorphism and bladder cancer susceptibility. We evaluated the quality of studies using the NewcastleOttawa Scale. (http://www.ohri.ca/programs/clinical_ epidemiology/oxford.asp) Scores 7 to 9 were defined as a high quality study, and a score $<7$ as a low quality study.

\section{Statistical analyses}

A meta-analysis was performed to reveal the association between GSTM1/GSTT1 deletion polymorphisms and bladder cancer susceptibility. Subgroup analyses were performed on different ethnicity, populationbased and smoking status. Statistical heterogeneity was assessed using a formal Q-statistic as well as $\mathrm{I}^{2}$ [80], $\mathrm{P}<0.05$ was considered statistically significant. A fixedeffect model was used when no heterogeneity was found; otherwise, the random-effect model was used to calculate pooled ORs. To validate the stability of results in this metaanalysis, a sensitivity analysis was carried out by sequential omitting each study and analyzing whether the significance of ORs was influenced excessively by omitting the study. Publication bias was evaluated by Egger's regression asymmetry test [81], and Begg's adjusted rank correlation test [82]; $\mathrm{P}<0.05$ was considered statistically significant. All analyses were performed using the STATA 11.0 statistical software (Stata Corp, College Station, TX, USA).

\section{CONFLICTS OF INTEREST}

The authors have declared no conflicts of interest

\section{FUNDING}

This work was supported by the National Natural Science Foundation of China (81572523) and the Fundamental Research Funds for the Central Universities of Central South University (2015zzts109).

\section{REFERENCES}

1. Siegel RL, Miller KD and A. J. Cancer statistics, 2016. CA Cancer J Clin. 2016; 66:7.

2. Ferlay J, Shin HR, Bray F, Forman D, Mathers C and DM P. Estimates of worldwide burden of cancer in 2008: GLOBOCAN 2008. Int J Cancer. 2010; 127:917.

3. Kamat AM, Hahn NM, Efstathiou JA, Lerner SP, Malmström PU, Choi W, Guo CC, Lotan Y and W. K. Bladder cancer. Lancet. 2016; S0140:8. 
4. Brinkman MT, Buntinx F, Kellen E, Dagnelie PC, Van Dongen MC, Muls E and MP Z. Dietary intake of micronutrients and the risk of developing bladder cancer: results from the Belgian case-control study on bladder cancer risk. Cancer Causes Control. 2011; 22:78.

5. Hengstler JG, Arand $\mathrm{M}$, Herrero $\mathrm{ME}$ and $\mathrm{F} O$. Polymorphisms of N-acetyltransferases, glutathione S-transferases, microsomal epoxide hydrolase and sulfotransferases: influence on cancer susceptibility. Recent Results Cancer Res. 1998; 154:85.

6. Li CG, Zhao ZM, Hu MG and R L. Predictive role of glutathione-S-transferase gene polymorphisms in risk and prognosis of hepatocellular carcinoma. Asian Pac J Cancer Prev. 2012; 13:52.

7. Csejtei A, Tibold A, Varga Z, Koltai K, Ember A, Orsos Z, Feher G, Horvath OP, Ember I and I. K. GSTM, GSTT and 53 polymorphisms as modifiers of clinical outcome in colorectal cancer. Anticancer Res. 2008; 28:22.

8. Slattery ML, Kampman E, Samowitz W, Caan BJ and JD P. Interplay between dietary inducers of GST and the GSTM-1 genotype in colon cancer. Int J Cancer. 2000; 87:33.

9. Zhang R, Xu G, Chen W and W. Z. Genetic polymorphisms of glutathione S-transferase M1 and bladder cancer risk: a meta-analysis of 26 studies. Mol Biol Rep. 2011; 38:7.

10. Jiang Z, Li C and X. W. Glutathione S-transferase M1 polymorphism and bladder cancer risk: a meta-analysis involving 33 studies. Exp Biol Med. 2011; 236:8.

11. Gong M, Dong W and R. A. Glutathione S-transferase T1 polymorphism contributes to bladder cancer risk: a metaanalysis involving 50 studies. DNA Cell Biol. 2012; 31:97.

12. Lin J, Kamat A, Gu J, Chen M, Dinney CP, Forman MR and X. W. Dietary intake of vegetables and fruits and the modification effects of GSTM1 and NAT2 genotypes on bladder cancer risk. Cancer Epidemiol Biomarkers Prev. 2009; $18: 7$.

13. Song DK, Xing DL, Zhang LR, Jiang X and Qiao BP. Relationship between polymorphism of glutathione Stransferase and genetic susceptibility to bladder cancer. Chin J Urol. 2008; 29:83.

14. Ceylan GG, Ceylan C, Taşdemir S and A. G. The effect of Glutathione-S-transferases in the susceptibility to bladder cancer. Ir J Med Sci. 2015; 184:4.

15. Matic MG, Coric VM, Savic-Radojevic AR, Bulat PV, PljesaErcegovac MS, Dragicevic DP, Djukic TI, Simic TP and TD.

P. Does occupational exposure to solvents and pesticides in association with glutathione S-transferase A1, M1, P1, and T1 polymorphisms increase the risk of bladder cancer? The Belgrade case-control study. PLoS One. 2014; 9:e99448.

16. Reszka E, Jablonowski Z, Wieczorek E, Jablonska E, Krol MB, Gromadzinska J, Grzegorczyk A, Sosnowski M and W. W. Polymorphisms of NRF2 and NRF2 target genes in urinary bladder cancer patients. J Cancer Res Clin Oncol. $2014 ; 140: 31$.
17. Berber U, Yilmaz I, Yilmaz O, Haholu A, Kucukodaci $\mathrm{Z}$, Ates $\mathrm{F}$ and D. D. CYP1A1 (Ile462Val), CYP1B1 (Ala119Ser and Val432Leu), GSTM1 (null), and GSTT1 (null) polymorphisms and bladder cancer risk in a Turkish population. Asian Pac J Cancer Prev. 2013; 14:9.

18. Kang HW, Song PH, Ha YS, Kim WT, Kim YJ, Yun SJ, Lee SC, Choi YH, Moon SK and WJ. K. Glutathione S-transferase M1 and T1 polymorphisms: susceptibility and outcomes in muscle invasive bladder cancer patients. Eur J Cancer. 2013; 49:9.

19. Henríquez-Hernández LA, Navarro P, Luzardo OP, AlvarezLeón EE, Boada LD, Zumbado M, Pestano J, Suárez JR, Chesa N, Almeida M and PF. V. Polymorphisms of glutathione S-transferase $\mu$ and $\theta$, MDR1 and VEGF genes as risk factors of bladder cancer: a case-control study. Urol Oncol. 2012; 30:5.

20. Schwender H, Selinski S, Blaszkewicz M, Marchan R, Ickstadt K, Golka K and JG. H. Distinct SNP combinations confer susceptibility to urinary bladder cancer in smokers and non-smokers. PLoS One. 2012; 7:e51880.

21. Lesseur C, Gilbert-Diamond D, Andrew AS, Ekstrom RM, Li Z, Kelsey KT, Marsit CJ and MR K. A casecontrol study of polymorphisms in xenobiotic and arsenic metabolism genes and arsenic-related bladder cancer in New Hampshire. Toxicol Lett. 2012; 210:6.

22. Zhang X, Lin J, Wu X, Lin Z, Ning B, Kadlubar S and FF. K. Association between GSTM1 copy number, promoter variants and susceptibility to urinary bladder cancer. Int $\mathbf{J}$ Mol Epidemiol Genet. 2012; 3:36.

23. Ovsiannikov D, Selinski S, Lehmann ML, Blaszkewicz M, Moormann O, Haenel MW, Hengstler JG and K. G. Polymorphic enzymes, urinary bladder cancer risk, and structural change in the local industry. J Toxicol Environ Health A. 2012; 75:65.

24. Marenne G, Real FX, Rothman N, Rodríguez-Santiago B, Pérez-Jurado L, Kogevinas M, García-Closas M, Silverman DT, Chanock SJ, Génin E and N. M. Genome-wide CNV analysis replicates the association between GSTM1 deletion and bladder cancer: a support for using continuous measurement from SNParray data. BMC Genomics. 2012; Jul:13.

25. Öztürk T, Kahraman ÖT, Toptaş B, Kisakesen Hİ, Çakalir C, Verim L, Öztürk O and T İ. The effect of CYP1A1 and GSTM1 gene polymorphisms in bladder cancer development in a Turkish population. In Vivo. 2011; 25:8.

26. Rouissi K, Ouerhani S, Hamrita B, Bougatef K, Marrakchi R, Cherif M, Ben Slama MR, Bouzouita M, Chebil M and A. BAE. Smoking and polymorphisms in xenobiotic metabolism and DNA repair genes are additive risk factors affecting bladder cancer in Northern Tunisia. Pathol Oncol Res. 2011; 17:86.

27. Salinas-Sánchez AS, Sánchez-Sánchez F, Donate-Moreno MJ, Rubio-del-Campo A, Gimenez-Bachs JM, LorenzoRomero JG, Serrano-Oviedo L and J. E. Polymorphic 
deletions of the GSTT1 and GSTM1 genes and susceptibility to bladder cancer. BJU Int. 2011; 107:32.

28. Moore LE, Baris DR, Figueroa JD, Garcia-Closas M, Karagas MR, Schwenn MR and AT J. GSTM1 null and NAT2 slow acetylation genotypes, smoking intensity and bladder cancer risk: results from the New England bladder cancer study and NAT2 meta-analysis. Carcinogenesis. 2011; 32:9.

29. Goerlitz D, El Daly M, Abdel-Hamid M, Saleh DA, Goldman L, El Kafrawy S and T. H. GSTM1, GSTT1 null variants, and GPX1 single nucleotide polymorphism are not associated with bladder cancer risk in Egypt. Cancer Epidemiol Biomarkers Prev. 2011; 20:4

30. Cantor KP, Villanueva CM, Silverman DT, Figueroa JD, Real FX, Garcia-Closas M and N M. Polymorphisms in GSTT1, GSTZ1, and CYP2E1, disinfection by-products, and risk of bladder cancer in Spain. Environ Health Perspect. 2010; 118:50.

31. Altayli E, Gunes S, Yilmaz AF, Goktas S and Y. B. CYP1A2, CYP2D6, GSTM1, GSTP1, and GSTT1 gene polymorphisms in patients with bladder cancer in a Turkish population. Int Urol Nephrol. 2009; 41:66.

32. Grando JP, Kuasne H, Losi-Guembarovski R, Sant'ana Rodrigues I, Matsuda HM, Fuganti PE, Gregório EP, Júnior FL, de Menezes RP, de Freitas Rodrigues MA and IM. dSC. Association between polymorphisms in the biometabolism genes CYP1A1, GSTM1, GSTT1 and GSTP1 in bladder cancer. Clin Exp Med. 2009; 91:8.

33. Song DK, Xing DL, Zhang LR, Li ZX, Liu J and BP. Q. Association of NAT2, GSTM1, GSTT1, CYP2A6, and CYP2A13 gene polymorphisms with susceptibility and clinicopathologic characteristics of bladder cancer in Central China. Cancer Detect Prev. 2009; 32:23.

34. Zupa A, Sgambato A, Bianchino G, Improta G, Grieco V, LA Torre G, Campisi B, Traficante A, Aieta M and A C. GSTM1 and NAT2 polymorphisms and colon, lung and bladder cancer risk: a case-control study. Anticancer Res. 2009; 29:14.

35. Covolo L, Placidi D, Gelatti U, Carta A, Scotto Di Carlo A, Lodetti P, Piccichè A, Orizio G, Campagna M, Arici C and S. P. Bladder cancer, GSTs, NAT1, NAT2, SULT1A1, XRCC1, XRCC3, XPD genetic polymorphisms and coffee consumption: a case-control study. Eur J Epidemiol. 2008; 23:62.

36. Golka K, Schmidt T, Seidel T, Dietrich H, Roemer HC, Lohlein D, Reckwitz T, Sokeland J, Weistenhofer W, Blaszkewicz M and S. S. The influence of polymorphisms of glutathione S-transferases M1 and M3 on the development of human urothelial cancer. J Toxicol Environ Health A. 2008; 71:6.

37. Shao J, Gu M, Zhang Z, Xu Z, Hu Q and L Q. Genetic variants of the cytochrome $\mathrm{P} 450$ and glutathione S-transferase associated with risk of bladder cancer in a south-eastern Chinese population. Int J Urol. 2008; 15:21.
38. Cengiz M, Ozaydin A, Ozkilic AC and G D. The investigation of GSTT1, GSTM1 and SOD polymorphism in bladder cancer patients. Int Urol Nephrol. 2007; 39:8.

39. Murta-Nascimento C, Silverman DT, Kogevinas M, García-Closas M, Rothman N, Tardón A and R. G-C. Risk of bladder cancer associated with family history of cancer: do low-penetrance polymorphisms account for the increase in risk? Cancer Epidemiol Biomarkers Prev. 2007; 16:600.

40. Zhao H, Lin J, Grossman HB, Hernandez LM, Dinney CP and X. W. Dietary isothiocyanates, GSTM1, GSTT1, NAT2 polymorphisms and bladder cancer risk. Int J Cancer. 2007; 120:13.

41. Kellen E, Zeegers M, Paulussen A, Vlietinck R, Vlem EV, Veulemans $\mathrm{H}$ and F. B. Does occupational exposure to PAHs, diesel and aromatic amines interact with smoking and metabolic genetic polymorphisms to increase the risk on bladder cancer?; The Belgian case control study on bladder cancer risk. Cancer Lett. 2007; 245:51.

42. McGrath M, Michaud D and I. DV. Polymorphisms in GSTT1, GSTM1, NAT1 and NAT2 genes and bladder cancer risk in men and women. BMC Cancer. 2006; 6:6.

43. Kogevinas M, Fernandez F, Garcia-Closas M, Tardon A, Garcia-Closas R, Serra C and A C. Hair dye use is not associated with risk for bladder cancer: evidence from a case-control study in Spain. Eur J Cancer. 2006; 42:54.

44. García-Closas M, Malats N, Silverman D, Dosemeci M, Kogevinas M, Hein DW, Tardón A and C S. NAT2 slow acetylation, GSTM1 null genotype, and risk of bladder cancer: results from the Spanish Bladder Cancer Study and meta-analyses. Lancet. 2005; 366:59.

45. Karagas MR, Park S, Warren A, Hamilton J, Nelson HH, Mott LA and KT. K. Gender, smoking, glutathioneS-transferase variants and bladder cancer incidence: a population-based study. Cancer Lett. 2005; 291:9.

46. Kim EJ, Jeong P, Quan C, Kim J, Bae SC, Yoon SJ, Kang JW, Lee SC, Jun Wee J and WJ. K. Genotypes of TNFalpha, VEGF, hOGG1, GSTM1, and GSTT1: useful determinants for clinical outcome of bladder cancer. Urology. 2005; 65:5.

47. Sobti RC, Al-Badran AI, Sharma S, Sharma SK, Krishan A and H M. Genetic polymorphisms of CYP2D6, GSTM1, and GSTT1 genes and bladder cancer risk in North India. Cancer Genet Cytogenet. 2005; 156:5.

48. Srivastava DS, Mishra DK, Mandhani A, Mittal B, Kumar A and RD. M. Association of genetic polymorphism of glutathione S-transferase M1, T1, P1 and susceptibility to bladder cancer. Eur Urol. 2005; 48:44.

49. Broberg K, Björk J, Paulsson K, Höglund M and M A. Constitutional short telomeres are strong genetic susceptibility markers for bladder cancer. Carcinogenesis. 2005; 26:71.

50. Saad AA, O'Connor PJ, Mostafa MH, Metwalli NE, Cooper DP, Povey AC and GP. M. Glutathione S-transferase M1, $\mathrm{T} 1$ and $\mathrm{P} 1$ polymorphisms and bladder cancer risk in Egyptians. Int J Biol Markers. 2005; 20:3. 
51. Hung RJ, Boffetta P, Brennan P, Malaveille C, Hautefeuille A, Donato F, Gelatti U, Spaliviero M, Placidi D, Carta A, Scotto di Carlo A and S. P. GST, NAT, SULT1A1, CYP1B1 genetic polymorphisms, interactions with environmental exposures and bladder cancer risk in a high-risk population. Int J Cancer. 2004; 110:6.

52. Moore LE, Wiencke JK, Bates MN, Zheng S, Rey OA and $\mathrm{AH}$. S. Investigation of genetic polymorphisms and smoking in a bladder cancer case-control study in Argentina. Cancer Lett. 2004; 211:8.

53. Srivastava DS, Kumar A, Mittal B and RD. M. Polymorphism of GSTM1 and GSTT1 genes in bladder cancer: a study from North India. Arch Toxicol. 2004; 78:4.

54. Sanyal S, Festa F, Sakano S, Zhang Z, Steineck G, Norming U, Wijkström H, Larsson P, Kumar R and K. H. Polymorphisms in DNA repair and metabolic genes in bladder cancer. Carcinogenesis. 2004; 25:34.

55. Chen YC, Xu L, Guo YL, Su HJ, Smith TJ, Ryan LM, Lee MS and DC. C. Polymorphisms in GSTT1 and p53 and urinary transitional cell carcinoma in south-western Taiwan: a preliminary study. Biomarkers. 2004; 9:94.

56. Jong Jeong H, Jin Kim H, Young Seo I, Ju Kim H, Oh GJ, Cheon Chae S, Sik Lim J, Taeg Chung H and J. JK. Association between glutathione S-transferase M1 and T1 polymorphisms and increased risk for bladder cancer in Korean smokers. Cancer Lett. 2003; 202:9.

57. Gago-Dominguez M, Bell DA, Watson MA, Yuan JM, Castelao JE, Hein DW, Chan KK, Coetzee GA, Ross RK and MC Y. Permanent hair dyes and bladder cancer: risk modification by cytochrome P4501A2 and $\mathrm{N}$-acetyltransferases 1 and 2. Carcinogenesis. 2003; 24:9.

58. Giannakopoulos X, Charalabopoulos K, Baltogiannis D, Chatzikiriakidou A, Alamanos Y, Georgiou I, Evangelou A, Agnantis N and N. S. The role of N-acetyltransferase-2 and glutathione S-transferase on the risk and aggressiveness of bladder cancer. Anticancer Res. 2002; 22:4.

59. Lee SJ, Cho SH, Park SK, Kim SW, Park MS, Choi HY, Choi JY, Lee SY, Im HJ, Kim JY, Yoon KJ, Choi H, Shin SG, Park TW, Rothman N, Hirvonen A, et al. Combined effect of glutathione S-transferase M1 and T1 genotypes on bladder cancer risk. Cancer Lett. 2002; 177:9.

60. Ma QW, Lin GF, Chen JG and JH. S. Polymorphism of glutathione S-transferase T1, M1 and P1 genes in a Shanghai population: patients with occupational or non-occupational bladder cancer. Biomed Environ Sci. 2002; 15:60.

61. Kim WJ, Kim H, Kim CH, Lee MS, Oh BR, Lee HM and T. K. GSTT1-null genotype is a protective factor against bladder cancer. Urology. 2002; 60:8.

62. Aktas D, Ozen H, Atsu N, Tekin A, Sozen S and E T. Glutathione S-transferase M1 gene polymorphism in bladder cancer patients. a marker for invasive bladder cancer? Cancer Genet Cytogenet. 2001; 125:1.

63. Törüner GA, Akyerli C, Uçar A, Aki T, Atsu N, Ozen H, Tez M, Cetinkaya M and T. O. Polymorphisms of glutathione
S-transferase genes (GSTM1, GSTP1 and GSTT1) and bladder cancer susceptibility in the Turkish population. Arch Toxicol. 2001; 75:64.

64. Kim WJ, Lee HL, Lee SC, Kim YT and H. K. Polymorphisms of N-acetyltransferase 2, glutathione S-transferase mu and theta genes as risk factors of bladder cancer in relation to asthma and tuberculosis. J Urol. 2000; 164:13.

65. Schnakenberg E, Lustig M, Breuer R, Werdin R, Hübotter R, Dreikorn K and W S. Gender-specific effects of NAT2 and GSTM1 in bladder cancer. Clin Genet. 2000; 57:7.

66. Steinhoff C, Franke KH, Golka K, Thier R, Römer HC, Rötzel C, Ackermann R and WA S. Glutathione transferase isozyme genotypes in patients with prostate and bladder carcinoma. Arch Toxicol. 2000; 74:6.

67. Peluso M, Airoldi L, Magagnotti C, Fiorini L, Munnia A, Hautefeuille A, Malaveille C and P. V. White blood cell DNA adducts and fruit and vegetable consumption in bladder cancer. Carcinogenesis. 2000; 21:7.

68. Salagovic J, Kalina I, Habalová V, Hrivnák M, Valanský $\mathrm{L}$ and E. B. The role of human glutathione S-transferases M1 and T1 in individual susceptibility to bladder cancer. Physiol Res. 1999; 48:71.

69. Lee SJ, Kang D, Cho SH, Kim SU, Park MS, Choi HY and Choi W. Association of genetic polymorphism of glutathione s-transferase M1 and T1 and bladder cancer. J Korean Cancer Assoc. 1999; 31:555.

70. Abdel-Rahman SZ, Anwar WA, Abdel-Aal WE, Mostafa HM and WW. A. GSTM1 and GSTT1 genes are potential risk modifiers for bladder cancer. Cancer Detect Prev. 1998; 22:38.

71. Katoh T, Inatomi H, Kim H, Yang M, Matsumoto $\mathrm{T}$ and T. K. Effects of glutathione S-transferase (GST) M1 and GSTT1 genotypes on urothelial cancer risk. Cancer Lett. 1998; 132:52.

72. Salagovic J, Kalina I, Stubna J, Habalová V, Hrivnák M, Valanský L, Kohút A and E B. Genetic polymorphism of glutathione S-transferases M1 and T1 as a risk factor in lung and bladder cancers. Neoplasma. 1998; 45:7.

73. Brockmöller J, Cascorbi I, Kerb R and I. R. Combined analysis of inherited polymorphisms in arylamine $\mathrm{N}$-acetyltransferase 2, glutathione S-transferases M1 and T1, microsomal epoxide hydrolase, and cytochrome P450 enzymes as modulators of bladder cancer risk. Cancer Res. 1996; 56:25.

74. Kempkes M, Golka K, Reich S, Reckwitz T and HM. B. Glutathione S-transferase GSTM1 and GSTT1 null genotypes as potential risk factors for urothelial cancer of the bladder. Arch Toxicol. 1996; 71:6.

75. Djukic TI, Savic-Radojevic AR, Pekmezovic TD, Matic MG, Pljesa-Ercegovac MS, Coric VM, Radic TM, Suvakov SR, Krivic BN, Dragicevic DP and TP. S. Glutathione S-transferase T1, O1 and $\mathrm{O} 2$ polymorphisms are associated with survival in muscle invasive bladder cancer patients. PLoS One. 2013; 8.

76. Snyder R, Witz G and BD. G. The toxicology of benzene. Environ Health Perspect. 1993; 100:306. 
77. Wacholder S, Chanock S, Garcia-Closas M, El Ghormli L and N R. Assessing the probability that a positive report is false: an approach for molecular epidemiology studies. J Natl Cancer Inst. 2004; 96:42.

78. Knight A, Askling $\mathrm{J}$ and A E. Cancer incidence in a population-based cohort of patients with Wegener's granulomatosis. Int J Cancer. 2002; 100:5.

79. Moher D, Liberati A, Tetzlaff J and Altman DG. Preferred reporting items for systematic reviews and meta-analyses: the PRISMA statement. PLoS Med. 2009; 6:e1000097. doi: 1000010.1001371/journal.pmed.1000097. Epub 1002009 Jul 1000021.
80. Higgins JP, Thompson SG, Deeks JJ, Altman DG.T HJP, G TS, J DJ and G AD. Measuring inconsistency in metaanalyses. BMJ. 2003; 327:557.

81. Egger M, Davey Smith G, Schneider M, Minder C.M E, G DS, M S and C M. Bias in meta-analysis detected by a simple, graphical test. BMJ. 1997; 315:629.

82. Begg CB, Mazumdar M.B BC and M M. Operating characteristics of a rank correlation test for publication bias. Biometrics. 1994; 50: 1088. 